\title{
PEMBELAJARAN BERBASIS TIK DENGAN ASSESSMENT FOR LEARNING (AFL) DITINJAU DARI KEMAMPUAN SPASIAL SISWA KELAS VIII SMP NEGERI SE-KOTA BANJARMASIN
}

\author{
Asy'ari, Gunawan \\ STKIP PGRI Banjarmasin, STKIP PGRI Banjarmasin \\ asyari153@stkipbjm.ac.id, gunawan@stkipbjm.ac.id
}

\begin{abstract}
Abstrak: Jenis penelitian yang digunakan adalah penelitian dan pengembangan. Penelitian ini bertujuan untuk mengetahui proses dan hasil pengembangan model pembelajaran berbasis TIK dengan Assessment for Learning (AfL) melalui penilaian teman sejawat serta efektivitas pembelajaran berbasis TIK dengan AfL melalui penilaian teman sejawat terhadap hasil belajar siswa ditinjau dari kemampuan spasial siswa yang merupakan penelitian eksperimental semu dengan desain faktorial $3 \times 3$. Populasi dari penelitian ini adalah seluruh siswa kelas VIII SMPN Kota Banjarmasin. Sampel dalam penelitian ini berjumlah 262 orang. Teknik analisis data yang digunakan adalah uji ANOVA dua jalan dengan sel tak sama. Berdasarkan uji hipotesis, diperoleh kesimpulan sebagai berikut: (1) Hasil belajar siswa yang diberi perlakuan model pembelajaran berbasis TIK dengan AfL melalui penilaian teman sejawat lebih baik dari hasil belajar siswa yang diberi model pembelajaran berbasis TIK dan model pembelajaran konvensional. Selain itu, hasil belajar siswa yang diberi perlakuan model pembelajaran berbasis TIK lebih baik dari hasil belajar siswa yang diberi model pembelajaran konvensional. (2) Hasil belajar siswa yang mempunyai kemampuan spasial tinggi lebih baik dari hasil belajar siswa yang mempunyai kemampuan spasial sedang dan rendah. Selain itu, hasil belajar siswa yang mempunyai kemampuan spasial sedang lebih baik dari hasil belajar siswa yang mempunyai kemampuan spasial rendah.
\end{abstract}

\section{Kata Kunci: Assessment for Learning (AfL), Pembelajaran Berbasis TIK, Kemampuan Spasial}

Dewasa ini dunia pendidikan sedang dihadapkan pada berbagai perubahan dalam berbagai aspek kehidupan di masyarakat. Perubahan-perubahan itu disebabkan oleh perkembangan ilmu pengetahuan dan teknologi serta globalisasi yang melanda dunia, termasuk bangsa Indonesia. Dalam perubahan-perubahan itu, dunia pendidikan dituntut mampu memberikan kontribusi nyata yaitu peningkatan kualitas hasil dan pelayanan pendidikan kepada masyarakat. Seiring perkembangan serta kemajuan sains dan teknologi yang semakin pesat, dunia pendidikan pun perlu mengadakan inovasi atau pembaharuan dalam berbagai bidang, termasuk dalam strategi pelaksanaannya.
Oleh karena itu, pendidikan adalah masalah yang menarik untuk terus dikaji dan terus dikembangkan. Dalam pendidikan, matematika merupakan pengetahuan dasar yang diperlukan oleh siswa untuk menunjang keberhasilan belajarnya dalam menempuh pendidikan ke jenjang yang lebih tinggi. Matematika mempunyai peran strategis dalam proses pendidikan karena banyak cabang ilmu lain yang memanfaatkan matematika. Namun, kenyataannya matematika justru dianggap sebagai mata pelajaran yang sulit dipahami dan hanya orang-orang tertentu saja yang dapat mempelajarinya. Anggapan ini membuat siswa menjadi takut untuk 
mempelajari matematika dan juga dapat menyebabkan peserta didik terlebih dahulu merasa tidak mampu mengerjakan tugastugas yang diberikan oleh guru mereka di sekolah sehingga siswa menjadi pasif di dalam pembelajaran (Trianto, 2007: 25). Hal tersebut dapat berakibat pada prestasi matematika siswa yang kurang memuaskan.

Sistem pembelajaran konvensional di sekolah saat ini diyakini kurang efektif. Konsep-konsep kemampuan otak, kecerdasan, dan kreativitas telah berkembang dengan pesat seiring dengan kemajuan dalam bidang teknologi dan komunikasi. Perkembangan tersebut memberikan pengaruh terhadap penguatan yang ingin mengoreksi kelemahan dan kekurangan yang ada pada sistem pembelajaran konvensional. Dalam sistem konvensional, proses transfer of knowledge dilakukan dengan menggunakan papan tulis sebagai sarana utama, ruangan dikelola dengan format yang statis dan guru menjadi satu-satunya informan yang expect dalam bidangnya (teacher centered). Di era globalisasi saat ini TIK (Teknologi Informasi dan komunikasi) menjadi kebutuhan yang mendasar dalam menentukan kualitas dan efektivitas proses pembelajaran. Dryden dan Vos (2003) menyimpulkan dari hasil penelitian mereka bahwa dalam sistem pendidikan yang terbukti berhasil, citra diri ternyata lebih penting dari materi pelajaran. Dengan demikian, konsep pendidikan masa depan ialah diarahkan kepada bagaimana membangkitkan gairah siswa untuk belajar secara menyenangkan (how student learn). Salah satu pendekatan dan metode yang dapat digunakan untuk meningkatkan aspek tersebut ialah dengan pemanfaatan Information and Comunication Technology (ICT) dalam proses pembelajaran. Mean dalam Suryadi (2007) menerangkan bahwa kebutuhan masyarakat persekolahan untuk memanfaatkan teknologi dalam pembelajaran merupakan bagian dari reformasi pembelajaran. Selain membantu menciptakan kondusi belajar yang kondusif bagi siswa, peran penting dari teknologi informasi dan komunikasi dalam proses pembelajaran adalah menyediakan seperangkat media dan alat (tool) untuk mempermudah dan mempercepat pekerjaan siswa, serta tentu saja memberi keterampilan penggunaan teknologi tinggi (advance skill) (Suryadi, 2007: 92). Selain itu, antara siswa dan sumber-sumber belajar dapat terjadi kapan saja dan di mana saja tidak terbatas oleh ruang dan waktu (space and time), serta proses penyampaian dan penyajian materi pembelajaran maupun gagasan dapat menjadi lebih menarik dan menyenangkan. Dengan demikian, kehadiran dan kemajuan ICT di era komunikasi global saat ini telah memberikan peluang dan perluasan interaksi antara guru dan siswa, interaksi tidak hanya terbatas di ruang kelas saja, sehingga di rumah siswa dapat mengulangi materi dengan baik. Guru dapat memanfaatkan berbagai jenis media secara bersamaan dalam bentuk multimedia pembelajaran. Penggunaan multimedia interaktif yang memuat komponen audio-visual untuk penyampaian materi pembelajaran dapat menarik perhatian siswa untuk belajar, dan juga dapat memberikan kesempatan kepada siswa untuk melakukan eksperimen semu dan ekplorasi sehingga memberikan pengalaman belajar daripada hanya sekedar mendengar uraian guru. Kehadiran media dalam proses pembelajaran memiliki makna yang sangat urgen, ketidakjelasan materi yang disampaikan dapat dibantu dengan menghadirkan media sebagai perantara. Kerumitan materi yang akan disampaikan 
kepada anak dapat disederhanakan dengan media. Selain itu, media dapat mewakili apa yang kurang mampu diucapkan seorang guru melalui kata-kata atau kalimat tertentu. Bahkan materi yang abstrak dapat dikonkretkan melalui media.

Proses penilaian juga layak menjadi sorotan ketika terjadi ketimpangan dalam dunia pendidikan. Apabila dicermati sebenarnya praktik penilaian yang dilakukan secara tepat akan menghasilkan hasil belajar yang meningkat, yakni penilaian yang melibatkan siswa. Seperti yang diungkapkan oleh Nick (2010) bahwa "in the context of student assessment, innovation aims to produce students who are deep rather than surface learners, highly motivated, equipped with a range of transferable skills, active and reactive participants in the learning process". Dalam konteks penilaian siswa, inovasi bertujuan untuk menghasilkan siswa yang lebih baik daripada pembelajaran biasa, sangat termotivasi, dilengkapi dengan berbagai keterampilan, aktif dan reaktif siswa dalam proses pembelajaran. Di lain pihak seperti yang diungkapkan Crooks pada tahun 1995 dalam (Lu dan Law, 2011) "Assessment has an important influence on the strategis, motivation, and learning outcomes of students". Penilaian memiliki pengaruh penting pada satu strategi, motivasi, dan hasil belajar siswa. Dalam kenyataanya asesmen atau lebih dikenal penilaian dimaknai dalam hal yang kecil, yakni memberikan soal ujian untuk dikerjakan dan kemudian diberi nilai atau hasil atas ujian tersebut. Seperti diungkapkan oleh CERI (Centre for Educational Research and Innovation) (2008: 1) "Assessment is vital to the education process. In schools, the most visible assessments are summative." Penilaian sangat penting untuk proses pendidikan. Di sekolah, penilaian yang paling terlihat sumatif. Penyempitan makna penilaian tesebut menjadi problematika tersendiri dalam dunia pendidikan. Oleh sebab itu, diperlukan paradigma baru dalam penilaian supaya penilaian merupakan suatu kegiatan yang termasuk dalam proses pembelajaran sedemikian sehingga kegiatan penilaian dapat membantu dalam meningkatkan kualitas pembelajaran.

Pentingnya penilaian yang berbasis pada pembelajaran menjadikan adanya Assessment for Learning (AfL). "Assessment for Learning is the process of seeking and interpreting evidence for use by learners and their teachers to decide where the learners are in their learning, where they need to go next, and how best to get them there" (Assessment Reform Group dalam Knight, 2008:3). Menurut Musial, Nieminen, Thomas, Burke (2009: 7) "One key purpose for assessment is to provide feedback to learner". Salah satu tujuan utama penilaian ialah untuk memberikan umpan balik kepada siswa. Penegasan lebih lanjut terdapat dalam lampiran Peraturan Menteri Pendidikan Nasional Nomor 20 Tahun 2007 tanggal 11 Juni 2007 tentang Standar Penilaian Pendidikan pada poin E penilaian oleh pendidik, butir keenam menjelaskan mengenai kegiatan mengembalikan hasil pemeriksaan pekerjaan siswa disertai balikan/komentar yang mendidik serta pada butir ketujuh yang intinya memanfaatkan hasil penilaian untuk perbaikan pembelajaran.

Dengan memperhatikan keunggulan dan beberapa kelemahan model pembelajaran konvensional maupun pembelajaran berbasis TIK, pentingnya kegiatan penilaian untuk pembelajaran serta pentingnya peran aktif siswa dalam proses pembelajaran menjadikan perlunya inovasi 
suatu model pembelajaran. Inovasi model pembelajaran bisa diwujudkan dalam bentuk pengembangan model pembelajaran dengan cara model pembelajaran sudah ada untuk kemudian dikembangkan ataupun dikombinasikan dengan hal lain yang bisa menutupi kelemahan model pembelajaran tersebut. Dalam hal ini, beberapa kelemahan dalam model pembelajaran berbasis TIK bisa dikombinasikan dengan keunggulan dari AfL dan penilaian teman sejawat.

Selain model pembelajaran, salah satu faktor yang mempengaruhi prestasi belajar yang lain adalah kemampuan spasial siswa. Faktor tersebut menjadi penting dalam kaitannya dengan proses pembelajaran. Kemampuan spasial siswa juga merupakan salah satu faktor yang kemungkinan dapat mempengaruhi kegiatan pembelajaran, terutama dalam pembelajaran matematika. Diezman dan Watters (2000: 302) dalam jurnalnya menuliskan bahwa "Indeed, spatial intelligence has long been implicated in mathematics and science achievement at school" (Memang, kecerdasan spasial telah lama terlibat dalam prestasi matematika dan sains di sekolah). Tiap siswa memiliki tingkat kemampuan spasial yang berbeda, sehingga dalam pembelajaran guru harus memperhatikan tingkat kemampuan spasial yang dimiliki siswa agar siswa dapat dengan mudah memahami materi pembelajaran sehingga diharapkan prestasi belajar siswa dapat tercapai dengan baik. Kaitan antara model pembelajaran berbasis TIK dengan kemampuan spasial adalah dengan adanya kemampuan spasial yang dimiliki siswa, akan dapat membantu siswa dalam memahami materi pelajaran matematika karena siswa akan dapat lebih mudah memvisualisasikan, memahami letak dan perubahan gambar untuk menemukan suau konsep dari materi yang dipelajari.

Melalui permasalahan yang muncul, maka dalam penelitian ini yang menjadi pokok permasalahan, yaitu berkaitan dengan inovasi model pembelajaran, paradigma tentang penilaian dan pemilihan model pembelajaran. Oleh karena itu peneliti tertarik untuk melaksanakan penelitian pengembangan, yaitu pengembangan model pembelajaran berbasis TIK dengan Assessment for Learning (AfL) melalui penilaian teman sejawat pada pembelajaran matematika ditinjau dari kemampuan spasial siswa kelas VIII SMP Negeri di Kota Banjarmasin Tahun Ajaran 2016/2017.

\section{Metode Penelitian}

Jenis penelitian yang digunakan adalah penelitian dan pengembangan sedangkan prosedur penelitian mengacu kepada prosedur $\mathrm{R}$ dan $\mathrm{D}$ yang dikemukakan oleh Borg dan Gall dengan beberapa modifikasi. Berikut akan diuraikan langkah-langkah penelitian yang dilakukan: (1) Pengembangan model pembelajaran berbasis TIK dengan AfL melalui penilaian teman sejawat. Pengembangan model dalam penelitian ini dimaksudkan untuk mendapatkan suatu model pembelajaran dengan menerapkan pembelajaran berbasis TIK dengan AfL melalui penilaian teman sejawat yang dapat dipraktikkan secara nyata dalam proses belajar mengajar. Adapun tahapan dalam pengembangan model terdiri dari tujuh tahap, yaitu : (a) Studi literatur; (b) Perencanaan model pembelajaran berbasis TIK dengan AfL melalui penilaian teman sejawat; (c) Focus Group Discussion (FGD); (d) Pembuatan prototipe model; (e) Validasi model, (f) Uji coba model; (g) Penetapan model. (2) Uji 
efektivitas model. Pada uji efektivitas model, dilakukan komparasi hasil belajar siswa yang dikenai model pembelajaran berbasis TIK dengan AfL melalui teman sejawat dengan siswa yang tidak dikenai model tersebut. Uji efektivitas model ini adalah penelitian eksperimental semu (quasi-experimental research). Pada uji efektivitas ini dilakukan sebanyak enam kali pembelajaran, dan satu kali untuk ujian. Manipulasi variabel dalam penelitian ini dilakukan pada variabel bebas yaitu pembelajaran berbasis TIK dengan AfL melalui teman sejawat yang dikenakan terhadap kelas eksperimen pertama, model pembelajaran berbasis TIK yang dikenakan terhadap kelas eksperimen kedua, dan model pembelajaran konvensional dikenakan terhadap kelas kontrol. Variabel lain yang ikut mempengaruhi veriabel terikat adalah kemampuan spasial dari masing-masing siswa. Dalam tahap uji efektivitas ini, sekolah yang dipilih berbeda dengan sekolah yang dipakai ketika uji coba model pembelajaran. Selanjutnya untuk keperluan uji efektivitas model, dalam penelitian ini akan menggunakan penelitian eksperimental semu dengan desain fakatorial $3 \times 3$. Populasinya adalah seluruh siswa kelas VIII SMPN se-Kota Banjarmasin tahun pelajaran 2016/2017. Sampel dalam penelitian ini dipilih dengan teknik stratified cluster random sampling. SMP Negeri se-Kota Banjarmasin dikelompokkan ke dalam tiga kelompok (berdasarkan rerata nilai hasil UN siswa di sekolah), yaitu kelompok atas, sedang, dan bawah. Dari masing-masing kelompok kemudian dipilih satu sekolah secara acak. Sampel yang terpilih adalah SMPN 14 Banjarmasin (mewakili kelompok atas), SMPN 24 Banjarmasin (mewakili kelompok sedang) dan SMPN 17 Banjarmasin (mewakili kelompok bawah).
Dari masing-masing sekolah dipilih lagi tiga kelas secara acak dan akan diberikan perlakuan yang berbeda, yaitu pembelajaran berbasis TIK dengan AfL melalui penilaian teman sejawat, pembelajaran berbasis TIK, dan pembelajaran konvensional. Pada SMPN 14 Banjarmasin, kelas yang terpilih adalah kelas 8F, 8G, dan 8E. Pada SMPN 24 Banjarmasin, kelas yang terpilih adalah kelas 8G, 8E, dan 8D. Pada SMPN 17 Banjarmasin, kelas yang terpilih adalah kelas 8F, 8C, dan 8D. Sampel dalam penelitian ini berjumlah 262 siswa yang terdiri dari 84 siswa pada kelas eksperimen satu, 90 siswa pada kelas eksperimen dua dan 88 siswa pada kelas kontrol. Dalam penelitian ini terdapat dua variabel bebas yaitu model pembelajaran dan kemampuan spasial siswa dan satu variabel terikat yaitu hasil belajar matematika.

Teknik pengumpulan data menggunakan metode dokumentasi dan tes. Metode dokumentasi digunakan untuk mengumpulkan data kemampuan awal siswa, metode tes digunakan untuk mengumpulkan data hasil belajar, dan tes kemampuan spasial digunakan untuk mengumpulkan data kemampuan spasial siswa. Instrumen yang digunakan dalam penelitian ini berupa tes objektif bentuk pilihan ganda pada materi bangun ruang (kubus dan balok) dan tes kemampaun spasial (untuk membedakan kemampuan spasial dalam kategori tinggi, sedang atau rendah). Tes kemampuan spasial dan tes hasil belajar yang digunakan berupa tes objektif berbentuk pilihan ganda dengan empat alternatif jawaban dengan satu jawaban benar yang terdiri dari 20 soal. Pada penelitian ini, untuk mengukur tingkat kecerdasan spasial yang dimiliki siswa akan digunakan instrumen berupa tes yang disusun berdasarkan 5 komponen dari 
kecerdasan yang diungkapkan Mainer (Aszalos dan bako, 2004, hal.3), yaitu: spatial perception, visualization, mental rotation, spatial relation, dan spatial orientation.

Uji coba instrumen dilakukan di SMPN 23 Banjarmasin. Uji coba dilakukan untuk mengetahui apakah instrumen tes yang telah dibuat telah memenuhi syaratsyarat instrumen yang baik, yaitu validitas isi, daya beda, tingkat kesukaran dan reliabel. Untuk instrumen tes hasil belajar, mengacu pada kriteria yaitu validitas isi, daya pembeda ( $\mathrm{D} \geq 0,3)$, tingkat kesukaran $(0,3 \leq \mathrm{P} \leq 0,7)$, dan reliabilitas $\left(\mathrm{r}_{11} \geq 0,7\right)$, dari 30 butir soal yang diujicobakan diperoleh 20 butir soal yang digunakan sebagai alat pengambil data hasil belajar matematika siswa. Uji prasyarat analisis yaitu uji normalitas dengan Lilliefors dan uji homogenitas dengan uji Bartlett. Uji analisis data yang digunakan yaitu analisis variansi dua jalan dengan sel tak sama.

\section{Hasil Penelitian dan Pembahasan}

Hasil uji keseimbangan terhadap data kemampuan awal siswa diperoleh bahwa ketiga populasi mempunyai kemampuan awal yang sama. Data kemampuan awal siswa yaitu nilai ulangan akhir semester matematika kelas VIII semester gasal tahun pelajaran 2016/2017 yang diambil sebelum dilakukan penelitian baik pada kelompok eksperimen 1, pada kelompok eksperimen 2, maupun pada kelompok kontrol. Setelah eksperimen, didapatkan data hasil belajar matematika. Adapun rerata hasil belajar matematika kelompok eksperimen dan kelompok kontrol dapat dilihat pada Tabel 1 berikut.
Tabel 1. Rerata Masing-masing Sel dari Data Model Pembelajaran dan Kemampuan Spasial.

\begin{tabular}{|c|c|c|c|c|}
\hline I'cmbclayaran $(a)$ & \multicolumn{3}{|c|}{$\begin{array}{c}\text { Eemampuan Spasial } \\
\text { Siswन (b) }\end{array}$} & $\begin{array}{c}\text { R=talit } \\
\text { Marginal }\end{array}$ \\
\hline \multirow[b]{2}{*}{$\begin{array}{l}\text { Derl:asis TIK } \\
\text { dersianAIL }\left(a_{i}\right)\end{array}$} & \multicolumn{4}{|c|}{ Tinggi $(b$,$) Sedang (b ;) \operatorname{Rendah}\left(c_{3}\right)$} \\
\hline & 81,61 & 74,90 & 69,04 & 75 \\
\hline B=ibasis TIR $\left(\omega_{2}\right)$ & 76.07 & 70.37 & 67.90 & $69=5$ \\
\hline Konvensionsl $\left(a_{4}\right)$ & 70,31 & 55.31 & 57,96 & 61.72 \\
\hline Kcrata Marginal & 7594 & 5978 & 6321 & \\
\hline
\end{tabular}

Sebelum dilakukan analisis variansi dua jalan, terlebih dahulu dilakukan uji normalitas dan uji homogenitas sebagai uji prasyarat analisis variansi. Selanjutnya dilakukan uji analisis variansi dua jalan dengan sel tak sama. Rangkuman uji analisis variansi disajikan pada Tabel 2.

\section{Tabel 2. Rangkuman Analisis}

\begin{tabular}{|c|c|c|c|}
\hline \multicolumn{4}{|c|}{ Variansi Dua Jalan } \\
\hline Sumber & $J K$ & $d k$ & $R K$ \\
\hline Model pembelajaran (A) & $4650,130 ?$ & $7 \quad 2$ & 2325,065 \\
\hline $\begin{array}{l}\text { Kemampuan Spasial } \\
\text { Siswa }(B)\end{array}$ & 7022,200 & 2 & 3511,100 \\
\hline Interaksi $(A B)$ & 75,27274 & 4 & 18.8 .76 \\
\hline $\begin{array}{l}\text { Galat (G) } \\
\text { Total }\end{array}$ & $\begin{array}{l}38733.31 \\
5048092\end{array}$ & $\begin{array}{l}\text { (1) } \\
5 \quad 261\end{array}$ & 153,050 \\
\hline Fimnher & $F_{m}$ & $F_{a}$ & Keputusan \\
\hline $\begin{array}{l}\text { Model pembelajaran } \\
\text { (A) }\end{array}$ & 15,187 & 3,031 & $\mathrm{TH}_{\mathrm{CA}}$ ditrlak \\
\hline $\begin{array}{l}\text { Kemampuan Spasial } \\
\text { Kiswa (B) }\end{array}$ & 22.934 & 3,031 & $\mathrm{TI}_{\text {SE }}$ ditolak: \\
\hline Interaksi $(A B)$ & 0.1228 & 2,407 & $\begin{array}{l}\mathrm{H}_{\text {CAB }} \\
\text { ditcrima }\end{array}$ \\
\hline fralat (G) & - & - & - \\
\hline
\end{tabular}

Kesimpulan analisis variansi dua jalan dengan sel tak sama berdasarkan Tabel 2. adalah (1) Pada efek utama antar baris (A), siswa-siswa yang dikenai dengan model pembelajaran berbasis TIK dengan Assessment for Learning (AfL) melalui penilaian teman sejawat, pembelajaran berbasis TIK, dan konvensional memberikan efek yang berbeda terhadap hasil belajar matematika siswa. (2) Pada efek utama antar kolom (B), kemampuan spasial tinggi, sedang, dan rendah memberikan efek yang berbeda terhadap hasil belajar matematika. 
(3) Pada efek interaksi ( $A B)$, tidak terdapat interaksi antara model pembelajaran dan kemampuan spasial siswa terhadap hasil belajar matematika siswa.

Berdasarkan anava dua jalan diperoleh bahwa $\mathrm{H}_{0 \mathrm{~A}}$ ditolak, sehingga perlu dilakukan uji lanjut pasca analisis variansi dengan metode Scheffe' untuk uji komparasi antar baris. Rangkuman perhitungan uji lanjut rerata antar baris disajikan pada Tabel 3.

Tabel 3. Rangkuman Hasil Uji Komparasi Ganda Antar Baris

\begin{tabular}{cccl}
$\mathrm{H}_{6}$ & $\mathrm{~F}_{\text {obe }}$ & $\mathrm{F}_{\text {tabsl }}$ & Kepunisan IJji \\
\hline$\mu_{2}=\mu_{2}$ & 8,3986 & 6,062 & $\mathrm{H}_{0}$ ditolak \\
$\mu_{\mathrm{S}}=\mu_{3}$ & 29,666 & 6,062 & $\mathrm{H}_{\mathrm{j}}$ ditolak \\
$\mu_{2}-\mu_{3}$ & 6.8082 & 6,062 & $\mathrm{H}_{2}$ ditulak \\
\hline
\end{tabular}

Berdasarkan hasil analisis variansi dua jalan dengan sel tak sama untuk efek utama faktor A (model pembelajaran) diperoleh harga statistik uji $F_{a}=15,187$ dan $F_{(0,05,2,253)}=3,031$, ternyata $F_{a}>F_{(0,05,2,253)}$, sehingga $\mathrm{F}_{\mathrm{a}} \in \mathrm{DK}$ dengan demikian $\mathrm{H}_{0 \mathrm{~A}}$ ditolak. Karena $\mathrm{H}_{0 \mathrm{~A}}$ ditolak maka perlu dilakukan uji lanjut anava yaitu uji komparasi ganda. Berdasarkan Tabel 3 hasil uji komparasi antar baris pada masingmasing kategori model pembelajaran dan Tabel 1, diperoleh simpulan bahwa hasil belajar siswa yang diberi perlakuan model pembelajaran berbasis TIK dengan assessment for learning melalui penilaian teman sejawat lebih baik dari hasil belajar siswa yang diberi model pembelajaran berbasis TIK dan model pembelajaran konvensional. Selain itu, hasil belajar siswa yang diberi perlakuan model pembelajaran berbasis TIK lebih baik dari hasil belajar siswa yang diberi model pembelajaran konvensional. Hal ini dimungkinkan karena model pembelajaran berbasis TIK dengan Assesment For Learning merupakan model pembelajaran yang mendorong siswa untuk aktif dalam pembelajaran. Dalam model pembelajaran berbasis TIK dengan Assesment for Learning (AfL), siswa dituntut untuk aktif dalam belajar materi bangun ruang dengan pembelajaran berbasis komputer yang inovatif. Selain itu ditambah lagi dengan adanya penilaian teman sejawat siswa yang digunakan untuk mendapatkan partisipasi siswa melalui tulisan untuk dapat lebih mengoptimalkan kemampuan berpikir siswa dalam hal menilai teman sejawatnya secara tertulis. Sedangkan pada model pembelajaran konvensional guru lebih mendominasi pembelajaran sehingga siswa kurang aktif dalam memperoleh informasi yang disampaikan. Selain itu ada kecendrungan siswa acuh untuk bertanya pada gurunya apabila ada materi yang belum mereka pahami dan pembelajaran cenderung monoton sehingga siswa merasa jenuh dalam belajar. Menurut Muhibbin Syah (2008:165) seseorang siswa yang sedang dalam kejenuhan sistem akalnya tidak dapat bekerja sebagaimana yang diharapkan dalam memproses item-item informasi sehingga prestasi belajar dapat menurun. Sehingga dapat disimpulkan bahwa siswa yang diberi model pembelajaran berbasis TIK dengan Assesment for Learning (AfL) mempunyai hasil belajar matematika yang lebih baik dari siswa yang diberi model pembelajaran konvensional.

Berdasarkan anava dua jalan diperoleh bahwa $\mathrm{H}_{0 \mathrm{~B}}$ ditolak, sehingga perlu dilakukan uji lanjut pasca analisis variansi dengan metode Scheffe' untuk uji komparasi antar kolom. Rangkuman perhitungan uji lanjut rerata antar kolom disajikan pada Tabel 4. 
Tabel 4. Rangkuman Hasil Uji Komparasi Ganda Antar Kolom

\begin{tabular}{cccc}
$\mathrm{H}_{0}$ & $\mathrm{~F}_{\text {ob }}$ & $\mathrm{F}_{\text {tabel }}$ & Keputusan Uji \\
\hline$\mu_{3}=\mu_{2}$ & 11,0077 & 6.062 & $\mathrm{II}_{0}$ ditolak \\
$\mu_{3}-\mu_{3}$. & 44.7201 & 6,062 & $\mathrm{H}_{0}$ ditolak \\
$\mu_{2}=\mu_{3}$ & 12,4439 & 0,062 & $\mathrm{H}_{0}$ ditolak \\
\hline
\end{tabular}

Berdasarkan hasil analisis variansi dua jalan dengan sel tak sama untuk efek utama faktor B (tingkat kemandirian belajar matematika) diperoleh harga statistik uji $\mathrm{F}_{\mathrm{b}}$ $=22,934$ dan $F_{(0,05,2,253)}=3,031$, ternyata $F_{b}$

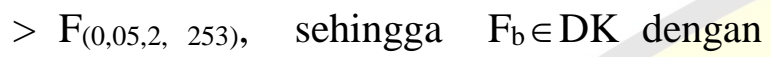
demikian $\mathrm{H}_{0 \mathrm{~B}}$ ditolak. Karena $\mathrm{H}_{0 \mathrm{~B}}$ ditolak maka perlu dilakukan uji lanjut anava yaitu uji komparasi ganda. Berdasarkan Tabel 4 hasil uji komparasi antar kolom pada masing-masing kategori kemampuan spasial matematika, diperoleh bahwa $\mathrm{H}_{0}$ ditolak. Hal ini berarti pada tingkat signifikansi $\alpha=$ 0,05 siswa yang memiliki kemampuan spasial tinggi secara signifikan memiliki hasil belajar matematika yang berbeda dengan siswa yang memiliki kemampuan spasial sedang, siswa yang memiliki kemampuan spasial tinggi secara signifikan memiliki hasil belajar matematika yang berbeda dengan siswa yang memiliki kemampuan spasial rendah, dan siswa yang memiliki kemampuan spasial sedang secara signifikan memiliki hasil belajar matematika yang berbeda dengan siswa yang memiliki kemampuan spasial rendah. Berdasarkan hasil rataan marginal dapat dilihat pada Tabel 1, diperoleh rerata hasil belajar matematika siswa yang memiliki kemampuan spasial tinggi 75,94, rerata hasil belajar siswa yang memiliki kemampuan sedang adalah 69,78 sedangkan rerata kemampuan spasial rendah sebesar 63,21.

Berdasarkan Tabel 4 hasil uji komparasi antar kolom pada masing-masing kategori kemampuan spasial matematika dan Tabel 1, diperoleh simpulan bahwa siswa dengan kemampuan spasial tinggi mempunyai hasil belajar lebih baik dibandingkan siswa dengan kemampuan spasial sedang dan rendah, dan siswa dengan kemampuan spasial sedang mempunyai hasil belajar lebih baik dibandingkan siswa dengan kemampuan spasial rendah. Hasil ini sesuai dengan hipotesis penelitian. Hal ini dikarenakan siswa yang memiliki kemampuan spasial tinggi mampu menerapkan kemampuan visualisasi yang dimiliki dalam materi sistem persamaan linear. Sehingga tujuan belajar tercapai dan menghasilkan hasil belajar yang lebih baik. Pendapat tersebut juga diperkuat oleh Ceket Palupi Waluyo yang dalam penelitiannya menyimpulkan bahwa siswa dengan kemampuan spasial tinggi mempunyai prestasi belajar yang lebih baik dari siswa dengan kemampuan spasial sedang maupun rendah sedangkan siswa yang mempunyai kemampuan spasial sedang memiliki prestasi yang lebih baik dibandingkan prestasi belajar matematika siswa yang mempunyai kemampuan spasial rendah (Ceket Palupi Waluyo, 2011, hal. 120).

Berdasarkan hasil perhitungan analisis variansi dua jalan sel tak sama pada efek interaksi AB (model pembelajaran dan tingkat kemampuan spasial siswa) diperoleh $\mathrm{F}_{\mathrm{AB}}=0,1228$ dan $D=\{F \mid F>2,465\}$, ini berarti $F_{A} \notin D$. Sehingga $\mathrm{H}_{0 \mathrm{AB}}$ diterima, sehingga tidak ada interaksi antara model pembelajaran dan kemampuan spasial terhadap hasil belajar siswa, sehingga tidak perlu dilakukan komparasi ganda antar sel. Artinya kesimpulan pada efek khusus (pada masing-masing model pembelajaran dan pada masing-masing kemampuan spasial) akan sejalan dengan kesimpulan pada efek utama yaitu (1) Pada kategori kemampuan spasial tinggi, sedang maupun rendah, antara 
model pembelajaran berbasis TIK dengan assessment for learning melalui penilaian teman sejawat memberikan hasil belajar lebih baik daripada model pembelajaran berbasis TIK dan model pembelajaran konvensional. Pada kategori kemampuan spasial tinggi, sedang maupun rendah, model pembelajaran berbasis TIK memberikan hasil belajar lebih baik daripada model pembelajaran konvensional.

(2) Pada model pembelajaran berbasis TIK dengan Assessment for Learning (AfL) melalui penilaian sejawat, pembelajaran berbasis TIK maupun model pembelajaran konvensional, siswa dengan kemampuan spasial tinggi mempunyai hasil belajar yang lebih baik daripada siswa dengan kemampuan spasial sedang maupun siswa dengan kemampuan spasial rendah, dan siswa dengan kemampuan spasial sedang mempunyai hasil belajar yang lebih baik daripada siswa dengan kemampuan spasial rendah.

\section{Simpulan dan Saran}

\section{Simpulan}

Berdasarkan hasil penelitian pengembangan, maka dapat disimpulkan syntax untuk model pembelajaran berbasis TIK dengan Assessment for Learning (AfL) melalui penilaian teman sejawat adalah sebagai berikut. 1) Pendahuluan, pada tahap ini guru menyampaikan tujuan pembelajaran dan motivasi kepada siswa. 2) Eksplorasi, guru menjelaskan materi pelajaran tentang bangun ruang sisi datar dengan menggunakan media pembelajaran berbantuan komputer yang diproyeksikan menggunakan LCD. Pada tahap ini guru memberikan stimulus bisa berupa pertanyaan-pertanyaan yang merangsang keingintahuan siswa maupun masalah yang berkaitan dengan materi yang disajikan dalam LKS. Pada tahap ini guru bersama siswa juga mendiskusikan materi yang dipelajari secara singkat. 3) Guru memberikan soal esensial yang bisa dikerjakan dalam waktu sekitar 10-15 menit, dan menyuruh siswa untuk memikirkan dan mengerjakan secara mandiri. 4) Setelah siswa mengerjakan soal, guru memintanya untuk berpasangan. Pada proses ini guru akan membagikan rubrik atau pedoman penilaian yang akan digunakan siswa untuk melakukan penilaian sejawat. Ketika proses penilaian sejawat dilakukan, guru tetap memberikan bimbingan jika ada siswa yang belum paham. 5) Setelah proses penilaian sejawat selesai, beberapa pasangan mempresentasikan hasil pengetahuan yang didapat pada proses penilaian sejawat. 6) Penutup, pada tahap ini hasil penilaian sejawat dikembalikan kepada pemiliknya untuk dijadikan koreksi bersama dan selanjutnya dikumpulkan kepada guru untuk diperiksa ulang dan diberi umpan balik, yang kemudian dikembalikan lagi kepada siswa pada pertemuan berikutnya (Pada tahap ini guru juga bisa memberikan pekerjaan rumah sebagai latihan soal untuk belajar siswa di rumah).

Berdasarkan hasil penelitian eksperimental semu dapat disimpulkan sebagai berikut. 1) Hasil belajar siswa yang diberi perlakuan model pembelajaran berbasis TIK dengan assessment for learning melalui penilaian teman sejawat lebih baik dari hasil belajar siswa yang diberi perlakuan model pembelajaran berbasis TIK dan model pembelajaran konvensional, dan hasil belajar siswa yang diberi perlakuan model pembelajaran berbasis TIK lebih baik dari hasil belajar 
siswa yang diberi perlakuan dengan menggunakan model pembelajaran konvensional, 2) Hasil belajar siswa yang memiliki kemampuan spasial tinggi lebih baik dari hasil belajar siswa yang memiliki kemampuan spasial sedang maupun rendah, dan hasil belajar siswa yang memiliki kemampuan spasial sedang lebih baik dari hasil belajar siswa yang memiliki kemampuan spasial rendah, 3) Pada model pembelajaran berbasis TIK dengan Assessment for Learning (AfL) melalui penilaian sejawat, pembelajaran berbasis TIK maupun model pembelajaran konvensional, siswa dengan kemampuan spasial tinggi mempunyai hasil belajar yang lebih baik daripada siswa dengan kemampuan spasial sedang maupun siswa dengan kemampuan spasial rendah, dan siswa dengan kemampuan spasial sedang mempunyai hasil belajar yang lebih baik daripada siswa dengan kemampuan spasial rendah, 4) Pada kategori kemampuan spasial tinggi, sedang maupun rendah, antara model pembelajaran berbasis TIK dengan assessment for learning melalui penilaian teman sejawat memberikan hasil belajar lebih baik daripada model pembelajaran berbasis TIK dan model pembelajaran konvensional. Pada kategori kemampuan spasial tinggi, sedang maupun rendah, model pembelajaran berbasis TIK memberikan hasil belajar lebih baik daripada model pembelajaran konvensional.

\section{Saran}

Berdasarkan simpulan, adapun saran dari hasil penelitian ini adalah bagi pendidik hendaknya model pembelajaran berbasis TIK dengan assessment for learning melalui penilaian teman sejawat ataupun model pembelajaran berbasis TIK dapat dijadikan sebagai salah satu referensi dalam pembelajaran matematika di kelas, karena berdasarkan hasil penelitian kedua model tersebut memberikan hasil belajar yang lebih baik dibandingkan model pembelajaran konvensional. Selain itu, guru hendaknya memperhatikan faktor lain dari dalam diri siswa yaitu kemampuan spasial siswa, karena dalam penelitian ini kemampuan spasial siswa memberikan pengaruh terhadap hasil belajar.

\section{Daftar Pustaka}

Aszalos, Laszlo, dan Maria Bako. (2004). How Can We Improve The Spatial Intelligence?. 6th International Conference on Applied Informatics Eger, Hungary. Diakses tanggal 11 Maret 2016 dari http://www.inf.unideb.hu/ aszalos/dn /pub/how.pdf.

\section{Ceket Palupi Waluyo. (2011).}

Eksperimentasi $\square \quad$ Pembelajaran Matematika dengan Model ThinkPair-Share (TPS) dan Model Two Sray- Two Stary (TSTS) pada Kompetensi Dasar Menghitung Luas Permukaan dan Volume Kubus, Balok, Prisma, dan Limas Ditinjau dari Kemampuan Spasial Siswa Kelas VIII SMP Kota Surakarta Tahun Pelajaran 2010/2011. Tesis. Tidak Diterbitkan. Universitas Sebelas Maret.

CERI. (2008). Assessment for Learning Formative Assessment.

Diezman, Carmel, M. and Watters, J. J. (2000). Identifying and supporting spatial intelligence in young children. Contemporary Issues in Early Childhood 1(3): 299-313. 
Dryden, G \& Vos, J. (2003). Revolusi Cara Belajar (The Learning Revolution). Bandung: Kaifa.

Knight, J. (2008). The Assessment for Learning Strategy.

Lu, J \& Law, N. (2011). Online Peer Assessment: Effects of Cognitive and Affective Feedback. Faculty of Education, The University of Hongkong. No.40: 257-275.

Muhibbin Syah. (2008). Psikologi Pendidikan dengan pendekatan Baru. Bandung : Remaja Rosdakarya.

Musial, D., Nieminen, G., Thomas, J., Burke, K. dkk. (2009). Foundations of Meaningful Educational Assesment. New York: McGraw-Hill.

Nick, Z. Z. (2010). Innovative Assessment For Learning Enhancement : Issue And Practices. Technological Education, Institute of Piraeus. Vol. 3, No. 1

Noonan, B. \& Duncan, C. R. (2005). Peer and self-assessment in high schools. Pratical Assessment, Research, \& Evaluation. Vol 10 number 17. 1-8.

Suryadi, Ace. (2007). Pemanfaatan ICT dalam Pembelajaran. Jurnal Pendidikan Terbuka dan Jarak Jauh. Volume 8, Nomor 1, Maret 2007,8398.

Trianto. (2007). Model Pembelajaran Inovatif. Jakarta: Bumi Aksara. 